\title{
The Hydrochemical Characteristics of a Stressed Sand-Gravel Aquifer: Kazan Plain, Ankara, Turkey
}

\author{
Ahmet Apaydin'1, Beril Salman Akin ${ }^{2 *}$, Eda Kaya ${ }^{3}$ \\ ${ }^{1}$ Civil Engineering Department, Giresun University, Giresun, Turkey \\ ${ }^{2}$ Department of Biology Teaching, Gazi Faculty of Education, Gazi University, Ankara, Turkey \\ ${ }^{3}$ Technical Research and Quality Control Department of General Directorate of State Hydraulic Works (DSI), Ankara, Turkey \\ Email: ^bsakin@gazi.edu.tr
}

How to cite this paper: Apaydin, A., Akin, B.S. and Kaya, E. (2021) The Hydrochemical Characteristics of a Stressed Sand-Gravel Aquifer: Kazan Plain, Ankara, Turkey. Journal of Environmental Protection, 12, 961-982. https://doi.org/10.4236/jep.2021.1211056

Received: October 9, 2021

Accepted: November 27, 2021

Published: November 30, 2021

Copyright (C) 2021 by author(s) and Scientific Research Publishing Inc. This work is licensed under the Creative Commons Attribution International License (CC BY 4.0).

http://creativecommons.org/licenses/by/4.0/ (c) (i) Open Access

\begin{abstract}
Over-exploitation and sand-gravel mining affect groundwater resources in terms of both quantity and quality. Groundwater level and well yields in and around the sand-gravel pits significantly decrease. Sand-gravel mining also changes the turbidity levels and temperature of groundwater. Reduction and destruction of valuable aquifers are significant issues. In this case, the natural state of the aquifer disappears. The Kazan Plain in central Turkey is a dramatic example of these kinds of results. The productive sand-gravel aquifer in the Kazan plain has been substantially damaged due to intensive sand-gravel mining since the 1980s. Additionally, over-exploitation has caused notable declines in groundwater levels, particularly in the 2000s. This study focuses on the hydrogeochemical situation of the Kazan Plain alluvium aquifer after intensive sand-gravel mining and over-exploitation. Groundwater samples were collected seasonally in 2015, five years after the over-exploitation and heavy sand-gravel mining. The decline reached $20 \mathrm{~m}$ (about half of the saturated thickness of the sand-gravel aquifer) in the region where the intensive groundwater abstraction lasted until 2010. Some quarries continued to operate until 2010, but after that mining activity continued only at a minimum level. Today, groundwater quality has been significantly degraded due to the over-exploitation of sand-gravel mining and also the cessation of recharge from fresh river water.
\end{abstract}

\section{Keywords}

Chemical Characteristic, Sand-Gravel Mining, Groundwater Over-Exploitation 


\section{Introduction}

Over-exploitation and pollution are the most common anthropogenic effect on groundwater resources in many parts of the words [1] [2] [3] [4]. Quarrying and sand-gravel mining are even more dangerous [2] [5]-[10] because they destroy the aquifers. The combination of all the above is the worst that can happen to an aquifer.

Over-exploitation and sand-gravel mining affect groundwater resources both in terms of quantity and quality [11]. The potential impact of sand-gravel pits includes lowering of the water level due to excavations and mine dewatering, changes in turbidity levels in groundwater due to operations, temperature change (thermal impact) in groundwater due to cropping out to the surface, and contamination [5]-[10] [12]. The most significant environmental impact of sand-gravel mining includes reduction and destruction of the aquifer volume [2] [13] [14]. The decrease in aquifer volume by excavations and the destruction and filling of the fine-grained materials of the pits change the natural porosity, hydraulic conductivity, and flow net. As the vadose zone is removed and groundwater ponds occur, evaporation losses increase at considerable levels. Additionally, the aquifer is exposed to atmospheric and anthropogenic pollution. Another effect of sand gravel mining is the change in the direction of the flow with the stress on the groundwater aquifers due to the changes in the surface of the land. These changes in the land surface can increase or decrease groundwater water supply by rainwater [15].

Over-exploitation is a serious problem for groundwater resources in Turkey as in most of the countries of the world. Groundwater levels decline in most aquifers of the country due to over-exploitation. In such aquifers, temporary or continual decline of groundwater level due to insufficient recharge in dry seasons and excessive groundwater exploitation make it difficult to obtain groundwater in practical and economical ways. Furthermore, in most regions of Turkey, Quaternary sand-gravel aquifers are under the threat of sand-gravel mining; some aquifers have already been damaged or mostly excavated [2] [13]. The Kazan Plain is one of these kinds of regions. The productive sand-gravel aquifer has been substantially damaged. Since the 1980s, the aquifer has been subjected to serious damages due to sand-gravel mining. Additionally, groundwater exploitation has intensified, and over-exploitation has caused a decline in groundwater levels, particularly in the 2000s.

This study focuses on the hydrogeochemical situation in the Kazan Plain alluvium aquifer after intensive sand-gravel mining and over-exploitation. Groundwater samples were collected seasonally in 2015, five years after the over-exploitation and heavy sand-gravel mining.

\section{Methodology}

\subsection{Study Area}

The Kazan Plain is located 25 - $30 \mathrm{~km}$ northwest of Ankara (Figure 1). Kazan is 


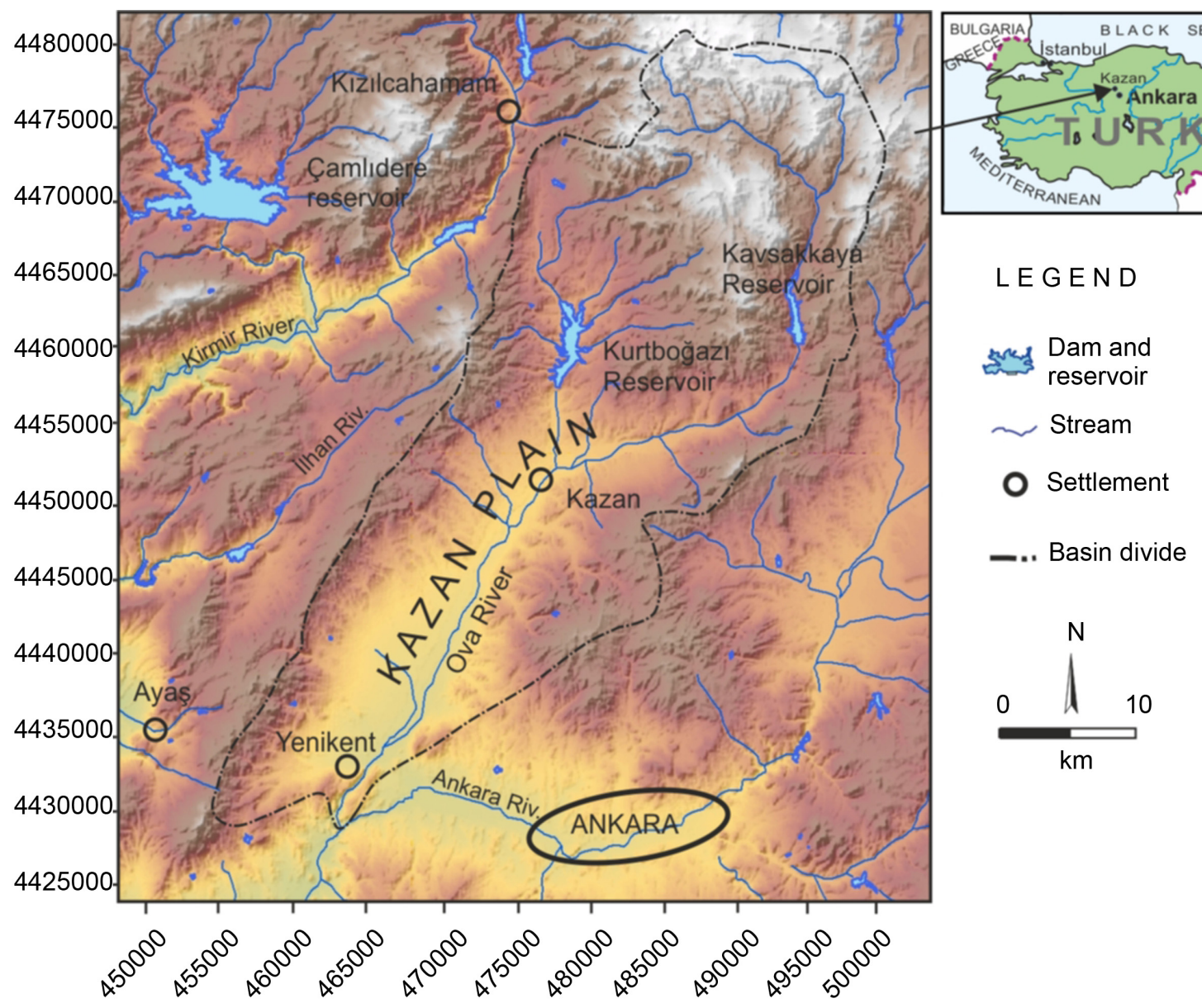

Figure 1. Location of the Kazan plain.

a town located upstream of the plain at the center of the basin. The total area of the basin is about $1550 \mathrm{~km}^{2}$; the area of the sand-gravel aquifer is $120 \mathrm{~km}^{2}$. The Ovacayi is the mainstream in the study area, and it drains into the basin [2]. A semi-arid climate prevails in the region. Summers are hot and arid, and winters are rainy and snowy. The annual average precipitation, potential evaporation, and temperature are $375 \mathrm{~mm}, 1180 \mathrm{~mm}$, and $118 \mathrm{C}$, respectively. The elevation varies from 750 to $2000 \mathrm{~m}$; the average elevation is about $1000 \mathrm{~m}$ in the basin. Minimum and maximum elevation in the plain is 800 and $975 \mathrm{~m}$, respectively.

The ovary is the mainstream of the basin. It used to flow throughout the year, but its discharges were reduced after the Kurtboğazı and Kavşakkaya dams were built. Additionally, large, deep sand-gravel pits destroyed the natural flow lines. Until the last year, there were many pits and piles of material along the stream bed. Some arrangements and restoration studies were made by the Turkish State Hydraulic Works (DSI) in the river bed; however, it was found that it was not possible to restore the aquifer. Quaternary alluvium (mostly sand and gravel) extends in the plain and along the secondary stream valleys connected with Ovacayi. Borehole data indicates that the thickness of the alluvium in the plain ranges between 15 and $45 \mathrm{~m}$. Alluvium does not exceed $20 \mathrm{~m}$ in thickness along 
the secondary valleys. The alluvium is mainly surrounded by Plio-Quaternary loose cemented sediments (mudstone, sandstone, and conglomerate) and Miocene gypsiferous formations (mudstone, sandstone, marl). Gypsiferous formations mainly extend in the middle and downstream of the plain.

\subsection{Sampling and Analysis}

In this study, the main chemical characteristics of the groundwater in the sandgravel aquifer that was stressed from over-exploitation and sand-gravel mining were investigated. In this context, the representative groundwater wells selected for sampling were reliable. Sampling was conducted in 15 sites during seasonal periods in 2015. The study area and water sample stations are shown in Figure 1 and Figure 2. DO, pH, and EC were measured in situ using a portable instrument. In the field, temperature and $\mathrm{pH}$ values were measured with a WTW $\mathrm{pH}$ 330i/SET device; electrical conductivity, total solids, salinity percentage, and parameters were measured with a WTW LF 330i/SET device.

Two bottles of samples were taken from each borehole and spring. Both samples were filtered, and one set of the bottles was acidified using $\mathrm{HNO}_{3}$ to prevent adsorption and chemical precipitation. Groundwater samples were stored at

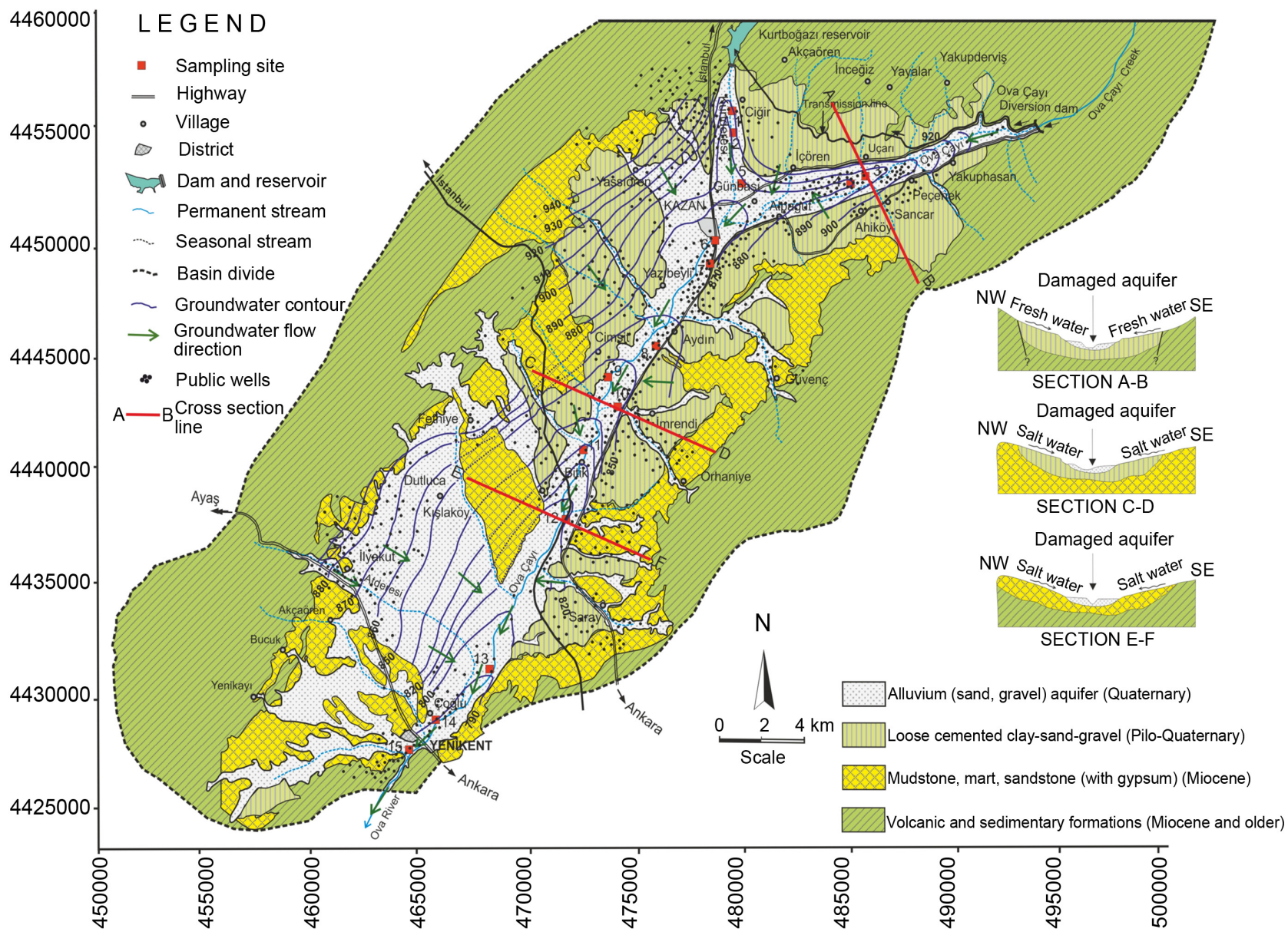

Figure 2. Generalized hydrogeological map of the Kazan Plain and vicinity. 
$+4^{\circ} \mathrm{C}$ until analysis. Chemical analyses were performed at the accredited laboratory of the State Hydraulic Works (DSI). All analyzes were performed under laboratory conditions; APHA-AWWA (2005) and TS standard measurement and analysis methods were applied. The determination of dissolved ions was carried out by the ion chromatography method (TS EN ISO 10304-1). Heavy metal analyzes were performed with an ICP-MS device [16]. The Na and SAR percentage values were determined according to the results of the analysis.

The four sets of chemical data (March 2015, June 2015, September 2015, and December 2015) were used to investigate the aerial distribution, seasonal changes, suitability for irrigation, and the relationship to geogenic and anthropogenic impacts. EC and some major ions were used to investigate the areal distribution of salinity along the groundwater flow paths. A contour map was used to illustrate the areal extent of the salinity. Composition, circular, and Schoeller diagrams were created to analyze the difference or similarity of the waters with each other. In addition, US Salinity Hazard and Wilcox diagrams were used to determining suitability for irrigation. Additionally, the recent chemical data representing the stressed and destroyed aquifer by sand-gravel mining were compared to the former data that represent the statue before destruction and over-exploitation (the 1960s).

\subsection{Hydrogeological Conceptual Model}

Unconsolidated Quaternary-age fluvial sand-gravel deposits (with subordinate clayey sand and silt) located in the Kazan plain is generally heterogeneous in vertical and horizontal directions. In the past, the best quality aquifer material was located along the Ovacayi Creek; however, it has been removed by the sand-gravel quarries. Pleo-Quaternary-age low permeable and loosely cemented conglomerates, sandstones and mudstones underlay and surrounded the sand-gravel aquifer (Figure 2) in the central and upstream sections. The sand-gravel aquifer is surrounded by Miocene-age lacustrine sediments containing gypsum and high sodium carbonate minerals in the downstream sections.

The saturated thickness ranged between $10 \mathrm{~m}$ and $25 \mathrm{~m}$ according to total alluvium thickness and water level fluctuations (it was 15 - $40 \mathrm{~m}$ before sand-gravel mining and over-exploitation). Maximum good yields ranged between 10 and 50 $1 / s$, and storage capacity was about $0.15-0.20$ before over-exploitation. With excavations lasting for 25 - 30 years, the aquifer was thinned or even removed in some places. Hence, groundwater levels and saturated thickness have declined over time. The aquifer is recharged from precipitation and partially from streamflow only in the wet seasons because the stream flows occur only after storm events and snowmelt for very short periods [2].

Significant sand-gravel mining and groundwater exploitation started at the end of the 1980s in the Kazan Plain. The original hydrogeological features of the Quaternary-age sand-gravel aquifer were determined before the exploitation and 
excavation by DSI. According to boreholes, geophysical soundings by DSI [17] [18], and excavation pits, the maximum thickness of the fluvial sand-gravel formation reached $45 \mathrm{~m}$. The formation was thicker in the upper part (the section north and east of the Ankara-Istanbul highway) of the plain [2]. The original thickness was preserved in a small area that had not been destroyed by sandgravel mining.

Reliable data on groundwater levels and groundwater contour maps representing the duration of the mid-1970s exist [18]. According to these data, the groundwater level ranged from 0 to $1 \mathrm{~m}$ in the upper section and 2.5 to $5 \mathrm{~m}$ in the lower section of the plain. In other words, the saturated thickness of the aquifer ranged from 15 to $45 \mathrm{~m}$ in the upper section and 2.5 to $27.5 \mathrm{~m}$ in the lower section. Consequently, the saturated thickness was at least $15 \mathrm{~m}$ near Ovacayi Creek in the lower section and $20 \mathrm{~m}$ in most regions in the upper section in the 1970s [2]. However, groundwater level and saturated thickness have been significantly reduced in the last 30 - 35 years because of the intensive sand-gravel mining and overexploitation. As of 2018, the saturated thickness has decreased by $5-15 \mathrm{~m}$ from the original state. This means that the aquifer has thinned by a third, and in fact, the situation was even worse eight years ago.

\section{Results and Discussion}

\subsection{Stresses on the Groundwater System}

\subsubsection{Sand-Gravel Mining}

Sand-gravel mining in the plain started after the 1980s and lasted, to some extent, into the 1990s. According to official records, a total of 16 sand-gravel pits became active in 1984. Some of them stopped their activity or were banned by the state in the 2000s. Large, deep pits, groundwater ponds, marshes and swamps, and stack material were seen in the plain at the beginning of the 1990s. Intensive excavations lasted until 2008 [2]. Sand-gravel mining was banned after 2006 by the local government due to its negative effects on the environment, particularly on the groundwater system. However, some quarries continued to operate until 2010. After then, mining activity continued only at a minimum.

Today, the valuable sand-gravel aquifer in the plain seems to have been destroyed by the quarries. The most valuable part of the aquifer, which extends along the Ovacayi and Kurtderesi creeks, was removed. In other words, the aquifer volume was reduced by excavations, and the natural hydraulic system was changed by filling the pits with impermeable clay. Large groundwater ponds, marshes, swamps, useless material piles, and pits are now the characteristic features of the plain (Figure 3, Figure 4).

\subsubsection{Over-Exploitation and Droughts}

Notable groundwater use began in 1988 in the Kazan Plain. Abstraction by well increased continuously from 1993 to 2006 and the total amount of annual groundwater use reached $14 \mathrm{million} \cdot \mathrm{m}^{3}$ in 2006.2007 and 2008 were dry years when groundwater utilization reached a maximum level due to the intensive 


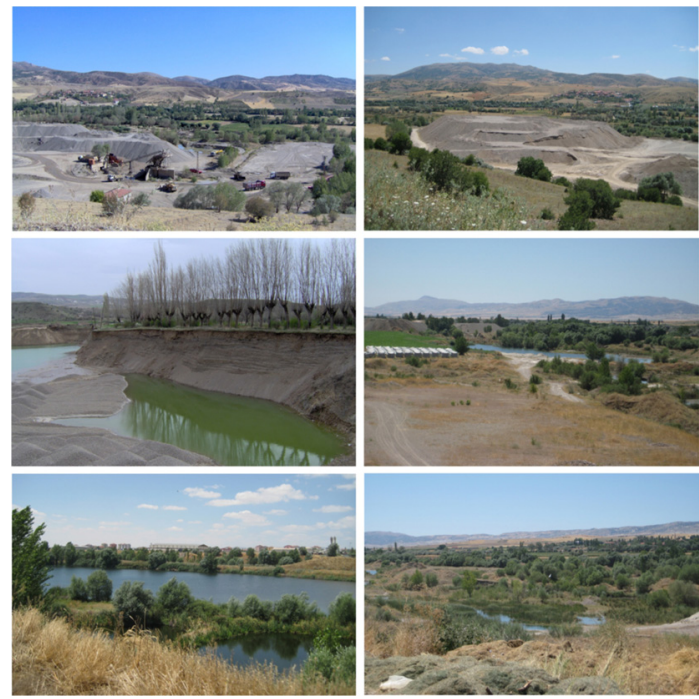

Figure 3. Some views of the sand-gravel mining and its effects in the Kazan Plain.

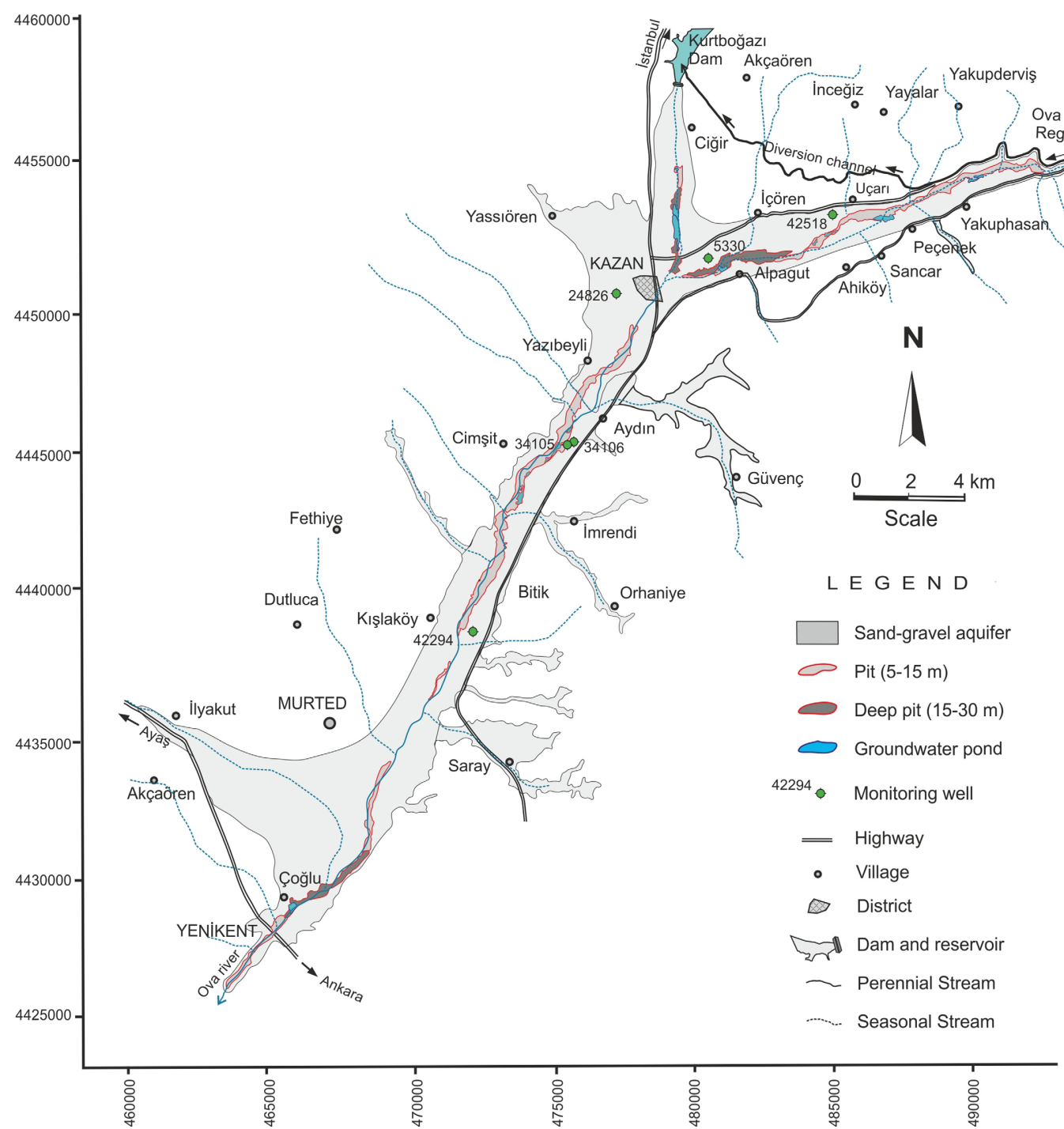

Figure 4. Map of the large, deep pits due to sand-gravel mining in the Kazan Plain as of October 2018. 
exploitation of 50 wells for the drinking water supply for Ankara. Seven million $\mathrm{m}^{3} /$ year was used for drinking water from the wells in a small area of the upstream section (Icoren-Ucari region). In 2008, a total of $15 \mathrm{million} \cdot \mathrm{m}^{3}$ of groundwater was abstracted from the sand-gravel aquifer [2]. After 2009, groundwater use decreased considerably due to decreased abstraction from the municipal drinking wells (Figure 5).

According to estimates, [18], the annual groundwater yield in the sand-gravel aquifer and the neighboring Plio-Quaternary semi aquifer was $15.5 \mathrm{million} \cdot \mathrm{m}^{3}$. This amount was estimated before the removal of some of the aquifer by sand-gravel mining.

The hydrograph of Well 42,294 represents a region that is not affected by over-exploitation and sand-gravel mining (Figure 6). In other words, this well represents nearly natural or original conditions. In this well, groundwater level fluctuates in a narrow range $(7-11 \mathrm{~m})$ and is followed by a horizontal course. Well, 34,106 and 34,107 are close to each other, but the trends of the hydrographs are slightly different. The groundwater level in Well 34,107 was affected by both groundwater exploitation and the excavations of the pits since 1973. A sand-gravel quarry has been in operation near the well from 1973 to 1985. Excavations expanded and deepened after 1995. Similarly, groundwater exploitation increased continuously in this area. The groundwater level in Well 34,106, which is located further from the quarry, was slightly affected by the excavations.

Until 1998, Well 24,826 had been under the impact of the sand-gravel mining located at the southern side of the aquifer; however, this impact had become steady because the excavation stopped in 1998. The graph of the well shows the influence of the intensive exploitation in the upper part of the aquifer. The previous groundwater level (between 1999-2005), which had been fluctuating between 5 and $6 \mathrm{~m}$, had dropped to $10 \mathrm{~m}$ in 2008 due to the intensive groundwater

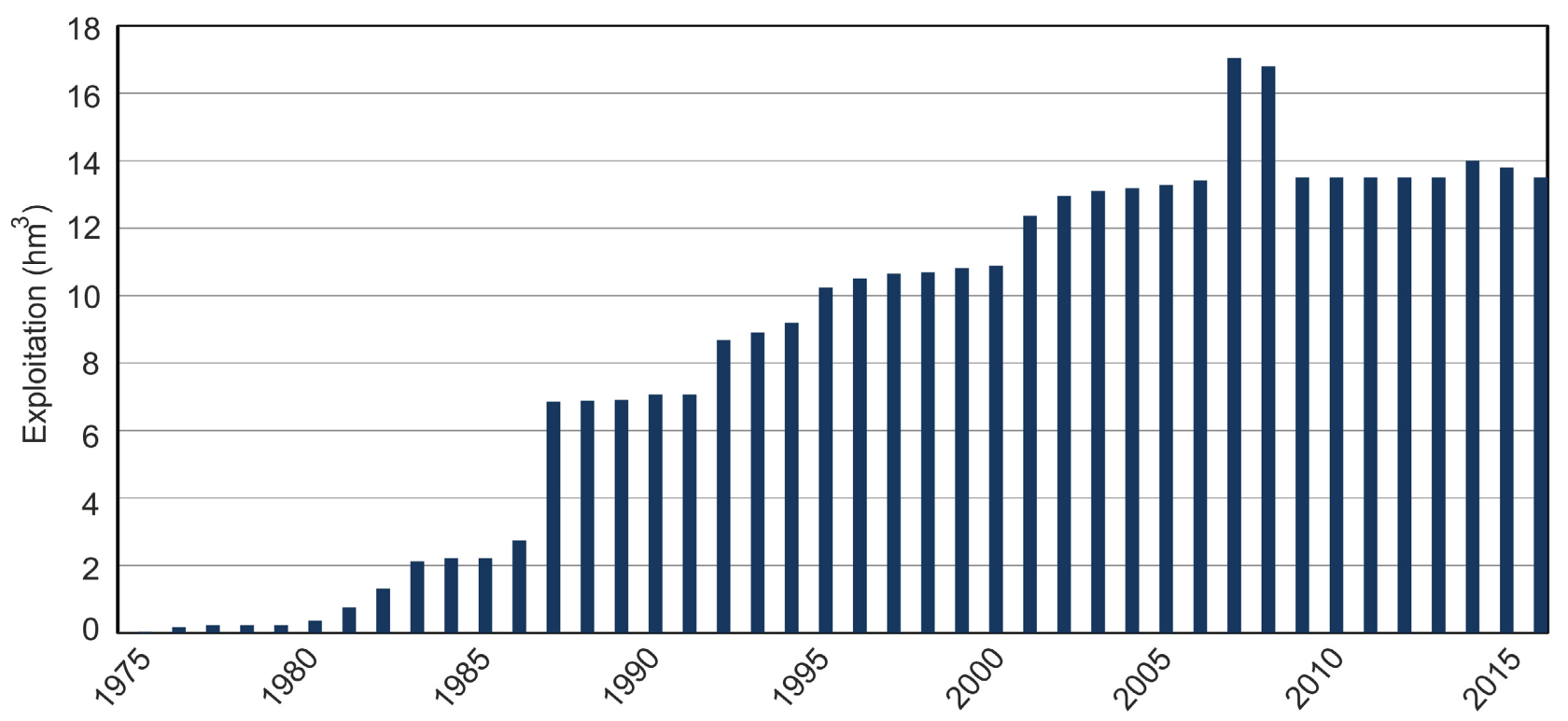

Figure 5. Temporal changes in groundwater exploitation in the Kazan Plain. 

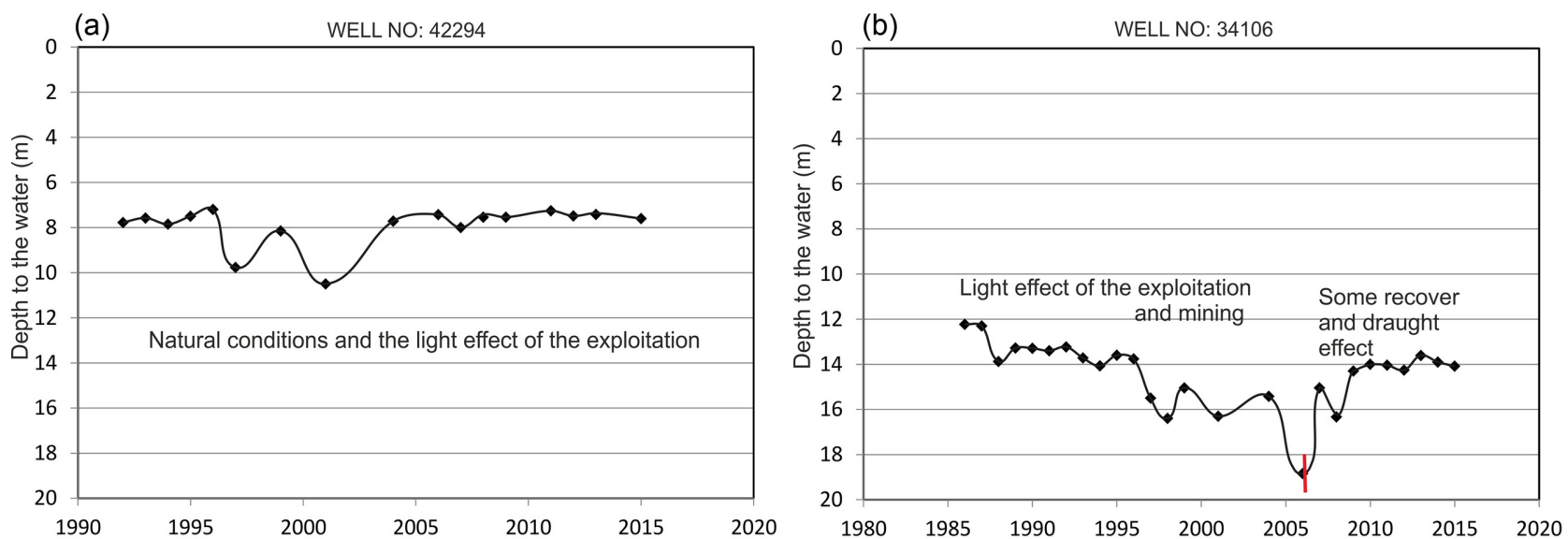

(c)

WELL NO: 42518

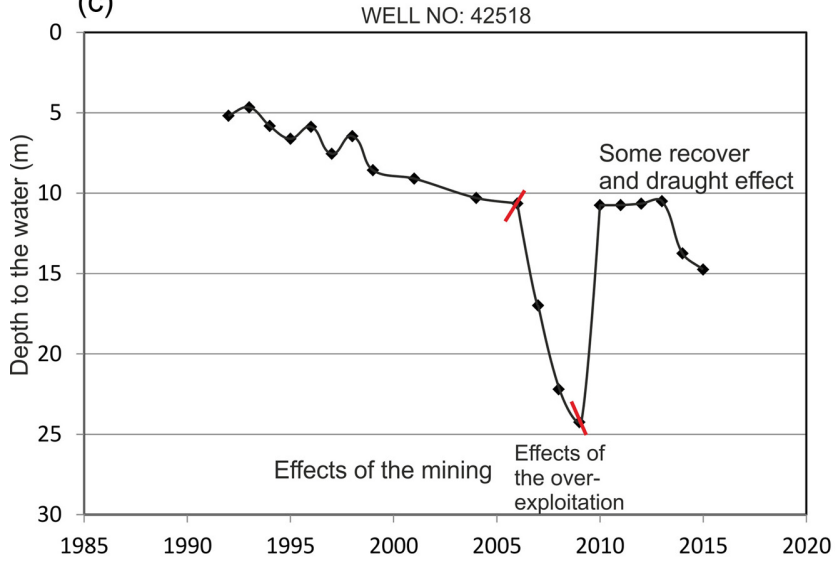

(d)
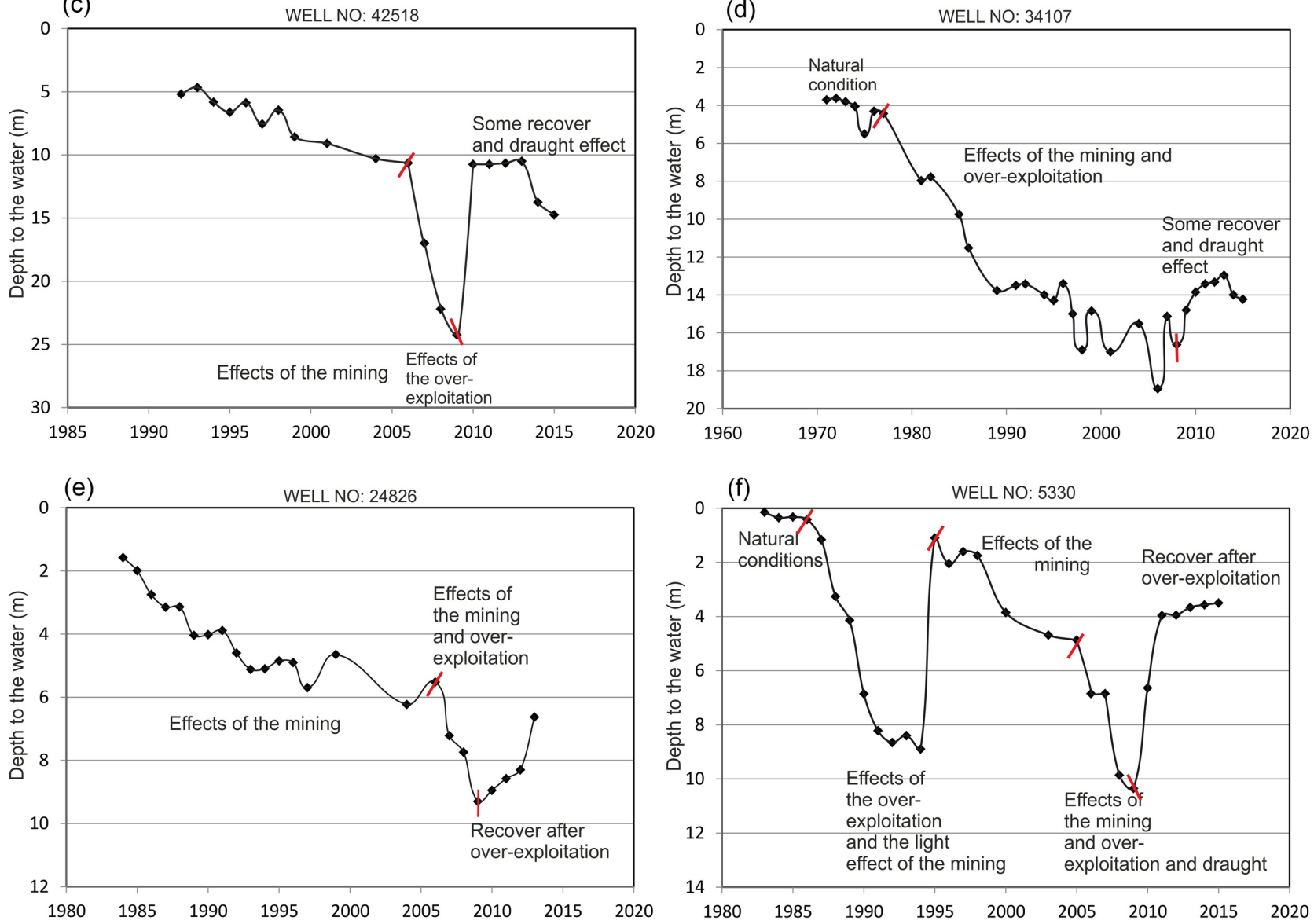

Figure 6. Some water level hydrographs regarding the exploitation and sand-gravel mining in the Kazan Plain.

abstraction. Well, 5330, which is located west of the village of Icoren was subjected to a slight impact from mining from 1980 to 1986. In this region that was affected intensively by the excavations of the pits from 1986 to 1994, the impact of the mining and the exploitation lasted until 2006; however, the over-exploitation, which started in 2006, caused a decline in the water level. The impact of the over-exploitation reached a maximum in the Icoren-Ucari region, in 2009. As seen in the graph of Well 42,518, the groundwater level, which fluctuated at 6 - 8 
$\mathrm{m}$, dropped to $15 \mathrm{~m}$ in 2008. The groundwater levels also dropped under $20 \mathrm{~m}$ in the other drinking water wells in this region. Consequently, the aquifer section located in the upper part of the plain and the vicinity of Kazan was affected by both over-exploitation and sand-gravel mining; furthermore, the other parts of the aquifer displayed different reactions to the local impact. There is no observation well between Yenikent and Coglu to assess the long-term changes in the water table. The older groundwater ponds in this region dried up in 2009 because of the declining groundwater table [2]. The average annual groundwater exploitation increased until 2006 and reached the maximum amount (17 million $\cdot \mathrm{m}^{3}$ ) in 2007 and 2008 due to over-exploitation for Ankara drinking water supply during the 2006-2008 drought. Groundwater use between 2010 and 2018 reduced to 13 to $14 \mathrm{million} \cdot \mathrm{m}^{3}$ after the drought.

\subsubsection{Agriculture and Industrial Activities}

The Kazan plain is a productive agricultural area. Since the soil, except for the lands destroyed by the quarries, is suitable for agriculture, and various crops can be grown. Sugar beets, dried beans, melons, watermelons, wheat, barley, and chickpeas are the most produced. In addition, in recent years, greenhouse cultivation has become a significant source of income for farmers. In addition to these cultivated agricultural products, cattle and poultry, beekeeping, and eggs are also produced. Kazan is also known for its famous plain melons, but the melon mostly is grown on slopes and arid lands. Fertilizers and pesticides coming from agricultural areas are the sources of indirect pollution of groundwater.

Today, there are 250 factories in the plain and the vicinity involved in the following: steel construction, machine assembly and manufacturing, petroleum products, agricultural medicine, food, construction, animal feed, chemicals, and transportation. In addition, TAI, which is an aerial platform in Turkey, is located downstream of the plain. Kazan and Yenikent are the major sources of urban pollution.

\subsubsection{Geogenic Pollution from the Adjacent Lacustrine Formations}

There are lacustrine formations containing gypsum around the Kazan plain (see Figure 2). The Miocene age sandstone-marl-mudstone formation contains gypsum and sodium carbonate. The aquifer is surrounded by evaporite-bearing formations in the central and downstream sections of the plain. Geogenic quality degradation in the sand-gravel aquifer was caused due to surface flow from the adjacent evaporite-bearing formations. Particularly in the downstream region, evaporitic lacustrine formations affect the groundwater quality of the sand-gravel aquifer, so much so that groundwater is becoming increasingly ionic moving downstream. In contrast, groundwater quality is rather high in the upstream section of the plain (upstream of the Kazan district) because the alluvium is surrounded by nonevaporitic formations in the upstream sections of the plain. 


\subsection{Hydro-Chemical Studies and Assessments}

\subsubsection{Water Quality}

Groundwater samples were collected as four sets in 15 sample sites, mostly from boreholes (Table 1). Minimum and maximum borehole depths were 10 and 55 $\mathrm{m}$, respectively, and the depth mostly ranged between 20 and $40 \mathrm{~m}$. The first and second sets of samples represented the wet season (collected in March and June), the second and fourth sets represented the end of the dry seasons (collected in September and December). Samples were collected following the pumping time when the $\mathrm{EC}$ and $\mathrm{pH}$ values had stabilized. Thus, the samples are a mix of each well. Temperature, $\mathrm{pH}$, and EC were measured in situ using a digital portable instrument. The sampling sites were selected according to the various geogenic and anthropogenic stresses (Table 2).

Table 1. The seasonal annual mean chemical characteristics of 15 groundwater sample sites (mg/l).

\begin{tabular}{|c|c|c|c|c|c|c|c|c|c|c|c|c|c|c|c|}
\hline Sample ID & 1 & 2 & 3 & 4 & 5 & 6 & 7 & 8 & 9 & 10 & 11 & 12 & 13 & 14 & 15 \\
\hline $\mathrm{pH}$ & 7.54 & 7.66 & 7.62 & 7.59 & 7.66 & 7.38 & 7.50 & 7.30 & 7.32 & 7.09 & 7.26 & 7.53 & 7.60 & 7.65 & 7.46 \\
\hline $\mathrm{EC}(\mu \mathrm{S} / \mathrm{c})$ & 376 & 408 & 598 & 594 & 573 & 685 & 547 & 1130 & 1226 & 765 & 1222 & 2260 & 1975 & 2775 & 3600 \\
\hline DO & 7.73 & 7.75 & 7.38 & 7.90 & 6.98 & 7.40 & 7.78 & 6.80 & 6.68 & 7.35 & 5.67 & 5.70 & 7.65 & 6.95 & 5.93 \\
\hline $\mathrm{Ca}$ & 24.62 & 55.62 & 57.00 & 49.17 & 42.17 & 60.25 & 34.07 & 58.57 & 96.64 & 87.59 & 160.2 & 163.0 & 76.95 & 108.8 & 73.90 \\
\hline $\mathrm{Mg}$ & 1.31 & 8.34 & 22.1 & 16.50 & 16.29 & 26.56 & 24.99 & 13.64 & 38.72 & 15.67 & 49.28 & 87.03 & 34.40 & 143.7 & 77.50 \\
\hline $\mathrm{Na}$ & 4.83 & 16.14 & 28.9 & 38.19 & 54.37 & 39.74 & 45.01 & 109.72 & 63.00 & 40.15 & 70.55 & 208.7 & 278.5 & 221.8 & 586.4 \\
\hline $\mathbf{K}$ & 3.00 & 4.02 & 4.12 & 8.07 & 4.75 & 4.21 & 3.75 & 1.85 & 4.25 & 0.98 & 9.50 & 10.46 & 7.88 & 6.48 & 9.30 \\
\hline $\mathrm{CO}_{3}$ & 0.00 & 0.00 & 0.00 & 0.00 & 0.00 & 0.00 & 0.00 & 0.00 & 0.00 & 0.00 & 0.00 & 0.00 & 0.00 & 0.00 & 0.00 \\
\hline $\mathrm{HCO}_{3}$ & 241.2 & 276.0 & 352.1 & 357.4 & 345.4 & 376.0 & 286.4 & 444.0 & 630.4 & 372.4 & 486.7 & 525.2 & 547.6 & 579.5 & 750.6 \\
\hline $\mathrm{Cl}$ & 7.87 & 4.55 & 7.12 & 6.83 & 9.97 & 14.14 & 13.85 & 54.95 & 50.01 & 31.03 & 52.59 & 159.8 & 216.3 & 312.9 & 592.7 \\
\hline $\mathrm{SO}_{4}$ & 3.30 & 10.77 & 46.47 & 48.90 & 13.14 & 47.96 & 26.04 & 32.45 & 68.96 & 49.33 & 242.2 & 725.8 & 279.7 & 486.6 & 548.8 \\
\hline $\mathrm{NO}_{3}$ & 5.16 & 4.41 & 7.01 & 8.47 & 9.36 & 30.15 & 23.30 & 41.19 & 112.32 & 54.62 & 14.78 & 6.60 & 5.23 & 187.6 & 20.97 \\
\hline B & 0.14 & 0.07 & 0.17 & 0.14 & 0.25 & 0.18 & 0.17 & 0.48 & 0.22 & 0.24 & 0.43 & 0.62 & 1.07 & 0.86 & 1.35 \\
\hline As & 0.04 & 0.02 & 0.01 & 0.01 & 0.02 & 0.01 & 0.01 & 0.03 & 0.00 & 0.02 & 0.02 & 0.01 & 0.01 & 0.03 & 0.04 \\
\hline $\mathrm{Mn}$ & 0.00 & 0.00 & 0.00 & 0.01 & 0.00 & 0.02 & 0.00 & 0.00 & 0.00 & 0.00 & 0.05 & 0.26 & 0.00 & 0.00 & 0.13 \\
\hline $\mathbf{F}$ & 0.80 & 0.93 & 1.80 & 1.89 & 0.97 & 1.66 & 0.70 & 2.21 & 2.43 & 1.76 & 2.48 & 0.89 & 1.34 & 2.56 & 2.45 \\
\hline $\mathbf{P}$ & 0.04 & 0.13 & 0.11 & 0.02 & 0.11 & 0.09 & 0.12 & 0.16 & 0.04 & 0.13 & 0.05 & 0.03 & 0.03 & 0.04 & 0.15 \\
\hline $\mathbf{N}_{2}$ & 1.20 & 1.00 & 1.58 & 2.19 & 2.11 & 6.81 & 5.26 & 9.30 & 25.36 & 12.33 & 3.34 & 1.49 & 1.18 & 42.37 & 4.73 \\
\hline $\mathrm{Na} \%$ & 6.75 & 17.00 & 22.25 & 29.67 & 40.50 & 26.50 & 34.00 & 52.75 & 25.75 & 24.50 & 21.33 & 36.00 & 62.50 & 35.00 & 70.25 \\
\hline SAR & 0.30 & 0.55 & 0.85 & 1.23 & 1.84 & 1.13 & 1.45 & 3.58 & 1.40 & 1.07 & 1.29 & 3.23 & 6.58 & 3.21 & 11.81 \\
\hline RSC & 0.26 & 1.19 & 1.22 & 2.04 & 2.31 & 1.31 & 1.05 & 3.25 & 3.26 & 0.80 & 0.00 & 0.00 & 1.97 & 0.00 & 2.68 \\
\hline
\end{tabular}


Table 2. The major stresses on the sampling sites.

\begin{tabular}{|c|c|c|}
\hline No & Sample Name & Potential or Current Stresses \\
\hline 1 & Cigar village well & $\begin{array}{l}\text { Agricultural activities, sand-gravel quarry due to the disclosure of groundwater, } \\
\text { waste materials derived from Cigar village }\end{array}$ \\
\hline 2 & $\begin{array}{l}\text { Anadolu Efes Biracilık ve Malt } \\
\text { Sanayi well }\end{array}$ & $\begin{array}{l}\text { Agricultural activities, sand-gravel quarry due to the disclosure of groundwater, } \\
\text { waste materials derived from Cigar village and the Efes brewery }\end{array}$ \\
\hline 3 & ASKI well, no: 35 & Agricultural activities, waste materials derived from Uçarı, sand-gravel mining \\
\hline 4 & ASKI well, no: 50 & Agricultural activities, waste materials derived from Uçarı, sand-gravel mining \\
\hline 5 & $\begin{array}{l}\text { ER-SAN Galvaniz ve Enerji } \\
\text { Sanayi A.S. well }\end{array}$ & $\begin{array}{l}\text { Agricultural activities, disclosure of groundwater due to sand-gravel mining, } \\
\text { waste materials derived from Ciğir, Efes brewery }\end{array}$ \\
\hline 6 & Yagmur Unlu Mamulleri well & Agricultural activities, Kazan urban waste, poultry farms \\
\hline 7 & $\begin{array}{l}\text { Kemal Türkoğlu Çelik } \\
\text { Makina well }\end{array}$ & $\begin{array}{l}\text { Agricultural activities, Kazan urban waste, poultry farms, industrial } \\
\text { institutions (steel factory) }\end{array}$ \\
\hline 8 & OZKA Prefabrik well & Agricultural activities, waste from Kazan and villages \\
\hline 9 & $\begin{array}{l}\text { Imrendi Altinisik Ciftligi DSI } \\
\text { well, no: } 45334\end{array}$ & Agricultural activities, waste from some villages, poultry farm \\
\hline 10 & Cimsit-ATAYOL A.S. well & $\begin{array}{l}\text { Agricultural activities, waste of the boiler and villages, the healing effect of } \\
\text { alluvial alluvium from Orhaniye }\end{array}$ \\
\hline 11 & Bitik-Ali Ozdemir well & $\begin{array}{l}\text { Agricultural activities, effect of old sand-gravel quarries, the effect of Kazan } \\
\text { and villages }\end{array}$ \\
\hline 12 & Kislakoy-Ahmet Dagdelen well & $\begin{array}{l}\text { Agricultural activities, effect of old sand-gravel quarries, the effect of Kazan } \\
\text { and villages, }\end{array}$ \\
\hline 13 & Sincan Cezaevi A-5 well & $\begin{array}{l}\text { Agricultural activities, effect of old sand-gravel quarries, the effect of Kazan } \\
\text { and villages, geogenic effect }\end{array}$ \\
\hline 14 & Çoglu-Safa Akbas well & $\begin{array}{l}\text { Agricultural activities, effect of old sand-gravel quarries, the effect of Kazan } \\
\text { and villages, geological effect, the effect of TAI and prison campus and } \\
\text { Çoğlu village wastes }\end{array}$ \\
\hline 15 & Yenikent-Cinar-Su well & $\begin{array}{l}\text { Agricultural activities, effect of old sand-gravel quarries, Kazan and the impact } \\
\text { of the villages, geogenic effect, the impact of prison campus and Çoğlu } \\
\text { village waste, Yenikent's sewage and all kinds of waste }\end{array}$ \\
\hline
\end{tabular}

\subsubsection{Spatial and Seasonal Changes in the Chemical Parameters}

Groundwater becomes increasingly ionic downstream in the Kazan Plain due to the effects of the evaporitic lacustrine formations. Ionization can be seen as a higher $\mathrm{Na}, \mathrm{Ca}, \mathrm{Mg}, \mathrm{HCO}_{3}, \mathrm{Cl}, \mathrm{SO}_{4}$, and $\mathrm{EC}$ (Figure 7). $\mathrm{EC}$ values that represent the total dissolved ion change between $250-1000 \mu \mathrm{S} / \mathrm{cm}$ upstream of Kazan, $1000-1500 \mu \mathrm{S} / \mathrm{cm}$ between Kazan and Batik (the central section of the plain), and $1500-2500 \mu \mathrm{S} / \mathrm{cm}$ between Batik and Coglu (the central and downstream sections). EC values reach the maximum $(4000-4500 \mu \mathrm{S} / \mathrm{cm})$ in the Yenikent-Coglu region where the waters are under the effect of all the anthropogenic and geogenic pollutants (Figure 8). The groundwater samples of the upstream region are the calcium-bicarbonate-type. $\mathrm{Na}, \mathrm{SO}_{4}$, and $\mathrm{Cl}$ contents are low or 

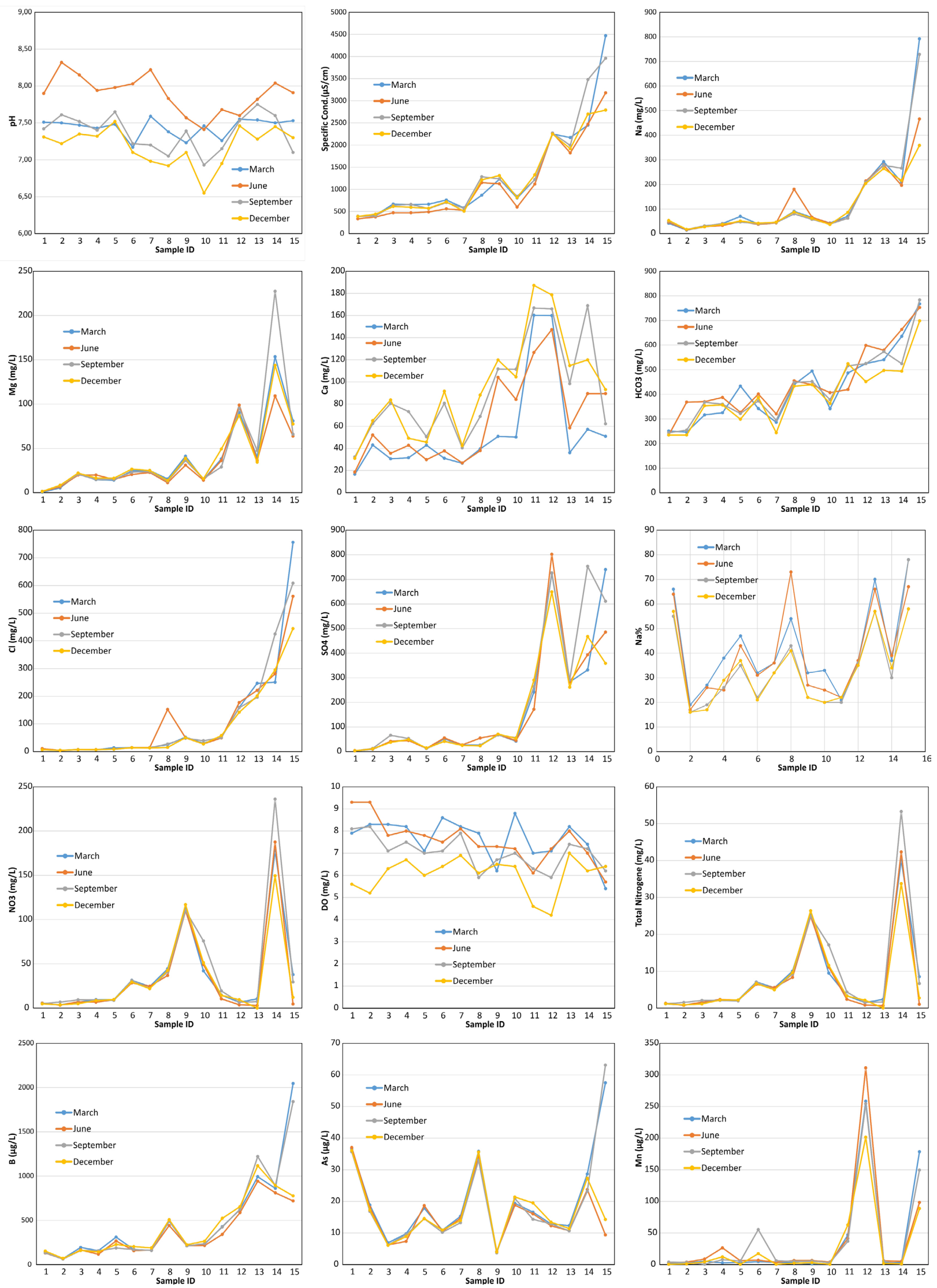

Figure 7. Changes of some species in the groundwater samples taken from the sand-gravel aquifer. 


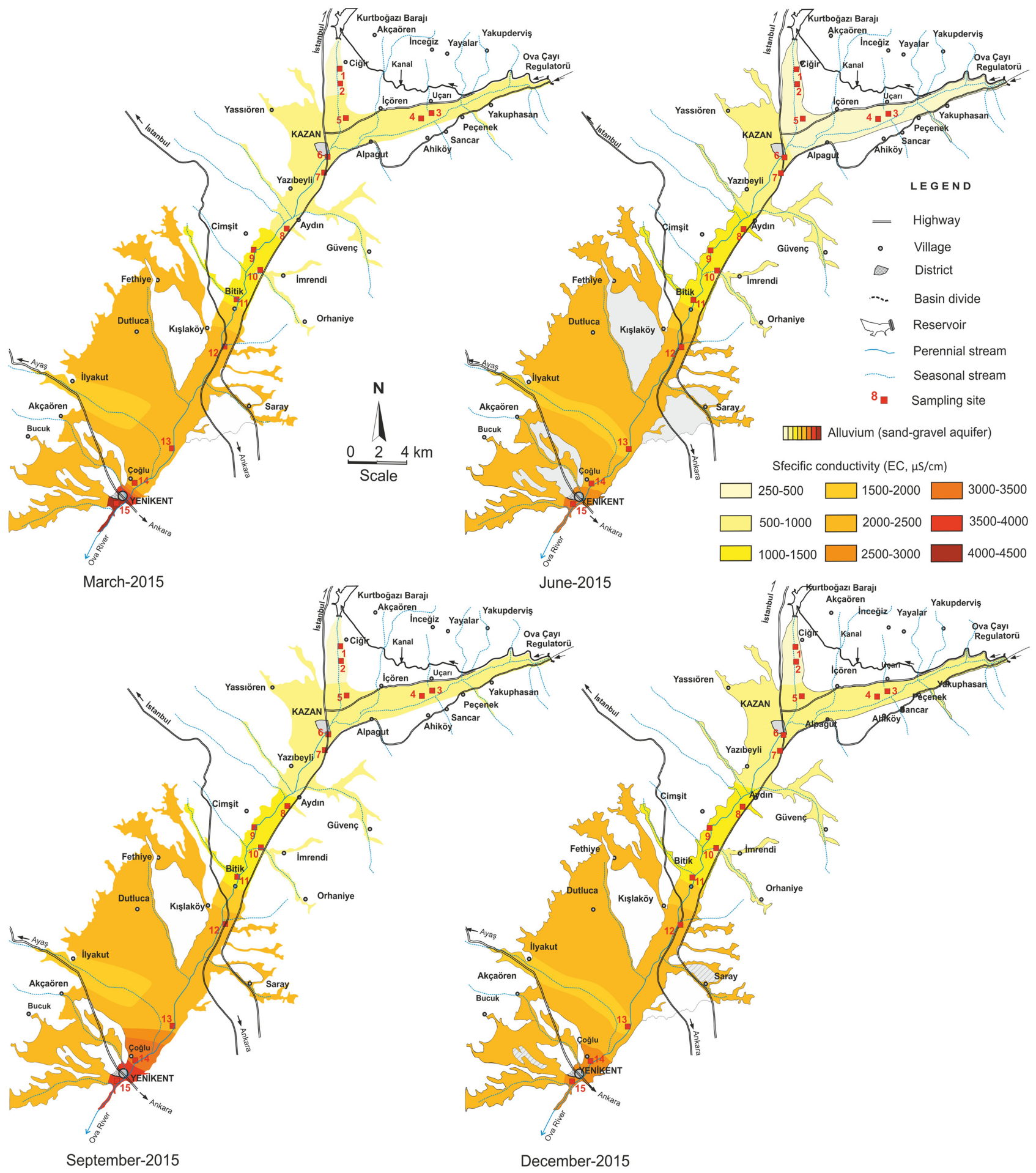

Figure 8. EC map of the groundwater samples.

moderate. Na cation slowly increases towards the middle of the plain, and the $\mathrm{Ca}-\mathrm{Na}$-bicarbonate water type changes into the Na-bicarbonate type. Sulfate in the waters of the downstream region also increases and almost equals the bicarbonate. In this region, $\mathrm{Na}$ cation and $\mathrm{SO}_{4}$ anion are dominant for the samples numbered 12, 14, and 15 . 
Seasonal changes in the chemical parameters along the flow path are as follows:

$\mathrm{pH}$ : Seasonal ranges are quite large. The ranges are narrower in the downstream area.

EC: In the upstream and the central region, the seasonal change is very low up to Site 13, but the range in the downstream region expands. The urban effect of Çoğlu, TAI, the prison campus, and Yenikent are dominant.

$\mathrm{Na}$ : The seasonal range expands only at Site 15.

Mg: Seasonal changes in the upstream and the middle sites are very small; the range enlarges at 14 and 15.

K. Seasonal change in the upstream and the middle region is less; only Site 4 breaks this rule where the range enlarges at point 15 .

Ca: Seasonal ranges at 1, 5, 7 are narrow, and the lines are very regular. $\mathrm{Ca}$ is too high at 12 .

$\mathrm{HCO}_{3}$ : There is not much difference between upstream and downstream in seasonal changes, and the range narrows in the middle sections.

$\mathrm{Cl}$ : Seasonal changes up to the downstream sites are minimal; ranges increase in the last three sites.

$\mathrm{SO}_{4}$ : $\mathrm{Up}$ to the last two points (14 and 15), overlapping lines are seen. At the last two sites, the ranges increase.

$\mathrm{NO}_{3}$ : The range is larger only at points 4 and 15; there is little seasonal change at other points.

B: Changes up to the last two sites are very small but increase at 15 .

As: Seasonal changes in the upstream and the middle sites are very small; the range enlarges at 15 .

$\mathrm{Mn}$ : Seasonal change is narrow at almost all the sites except for 15.

The dominant cation and anion in the upstream region of the plain are $\mathrm{Ca}$ and $\mathrm{HCO}_{3}$, respectively. Although this situation continues towards the central regions, the $\mathrm{Mg}, \mathrm{Na}$, and $\mathrm{SO}_{4}$ ions increase, and, finally, the ions in the downstream region are close to each other.

\subsubsection{Grouping of the Species by Using Composition Diagrams}

Composition diagrams were plotted to identify the sources of each element during the concentration process. In this context, diagrams of total dissolved solids (TDS) versus $\mathrm{Na}, \mathrm{Ca}, \mathrm{Mg}, \mathrm{HCO}_{3}, \mathrm{Cl}$, and $\mathrm{SO}_{4}$ were plotted (Figure 9). A linear relation was nearly achieved on the graphs of TDS versus $\mathrm{Na}, \mathrm{Cl}$, and $\mathrm{SO}_{4}$. TDS versus $\mathrm{Ca}$ and $\mathrm{Mg}$ values were scattered on the related graphs. Three main groups can be created according to the ion content in the TDS. The main groups were created as low, moderate, and high. From the upstream to the downstream in the plain, the waters demonstrate low, moderate, and, finally, high content of the selected species.

\subsubsection{Difference and Similarity of the Species in a Schoeller Diagram}

The water samples are located in two groups in the Schoeller diagrams (Figure 10): 1) waters with high-moderate $\mathrm{Ca}$ and high $\mathrm{Mg}-\mathrm{Na}$ with high $\mathrm{Cl}$ and $\mathrm{SO}_{4}$, 

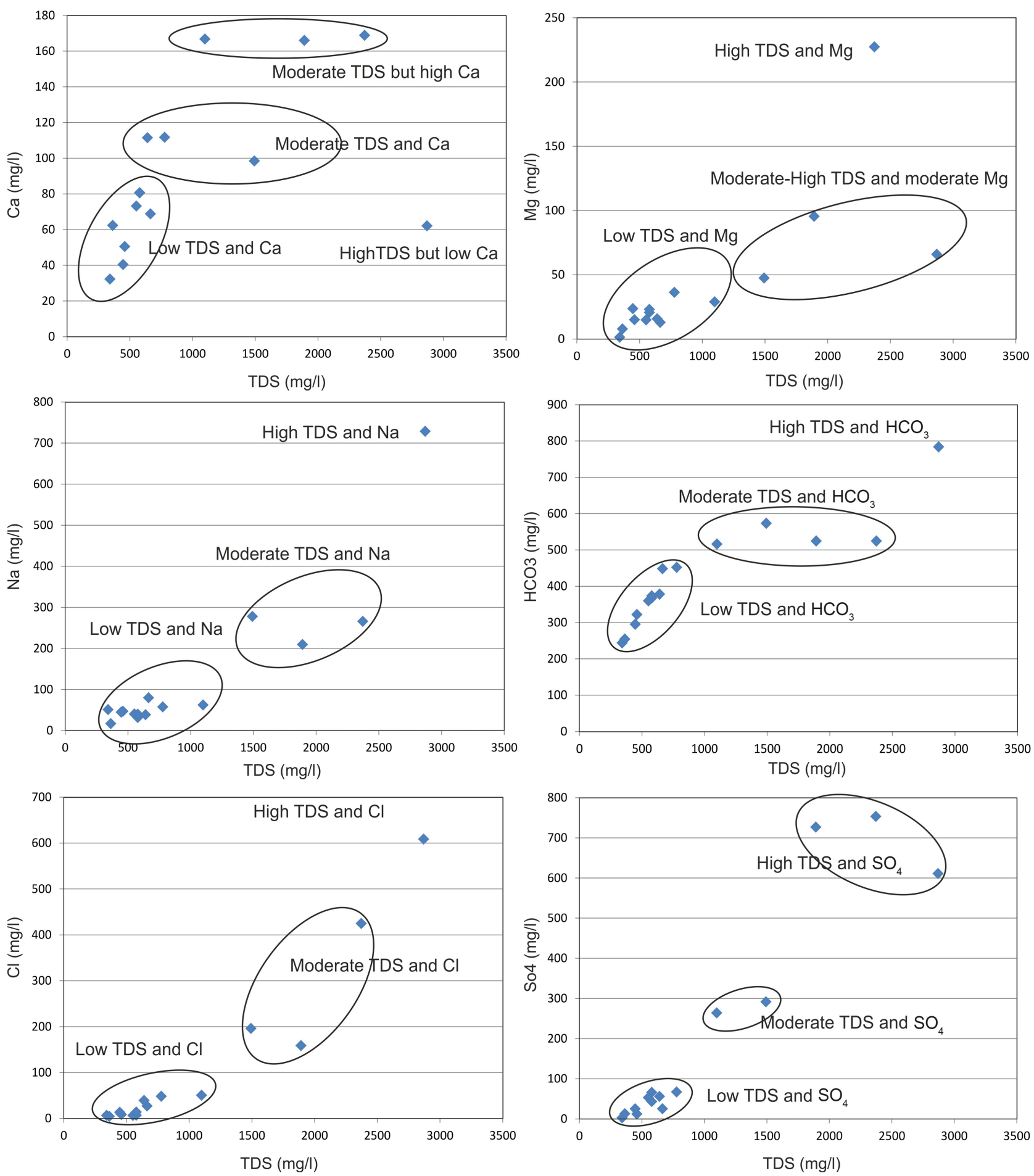

Figure 9. Composition diagrams.

and 2) waters with high-moderate $\mathrm{Ca}$ and low $\mathrm{Mg}-\mathrm{Na}$ with low $\mathrm{Cl}$ and $\mathrm{SO}_{4}$. All of the samples have a high $\mathrm{HCO}_{3}$. The upstream samples having low ion contents are located below the graphs, but the ones in the downstream region are located at the top. $\mathrm{Mg}$ and $\mathrm{SO}_{4}$ are generally the lowest, and $\mathrm{Na}$ and $\mathrm{HCO}_{3}$ are the highest. $\mathrm{Mg}, \mathrm{Cl}$, and $\mathrm{SO}_{4}$ are located over a wide range, and $\mathrm{HCO}_{3}$ is located 


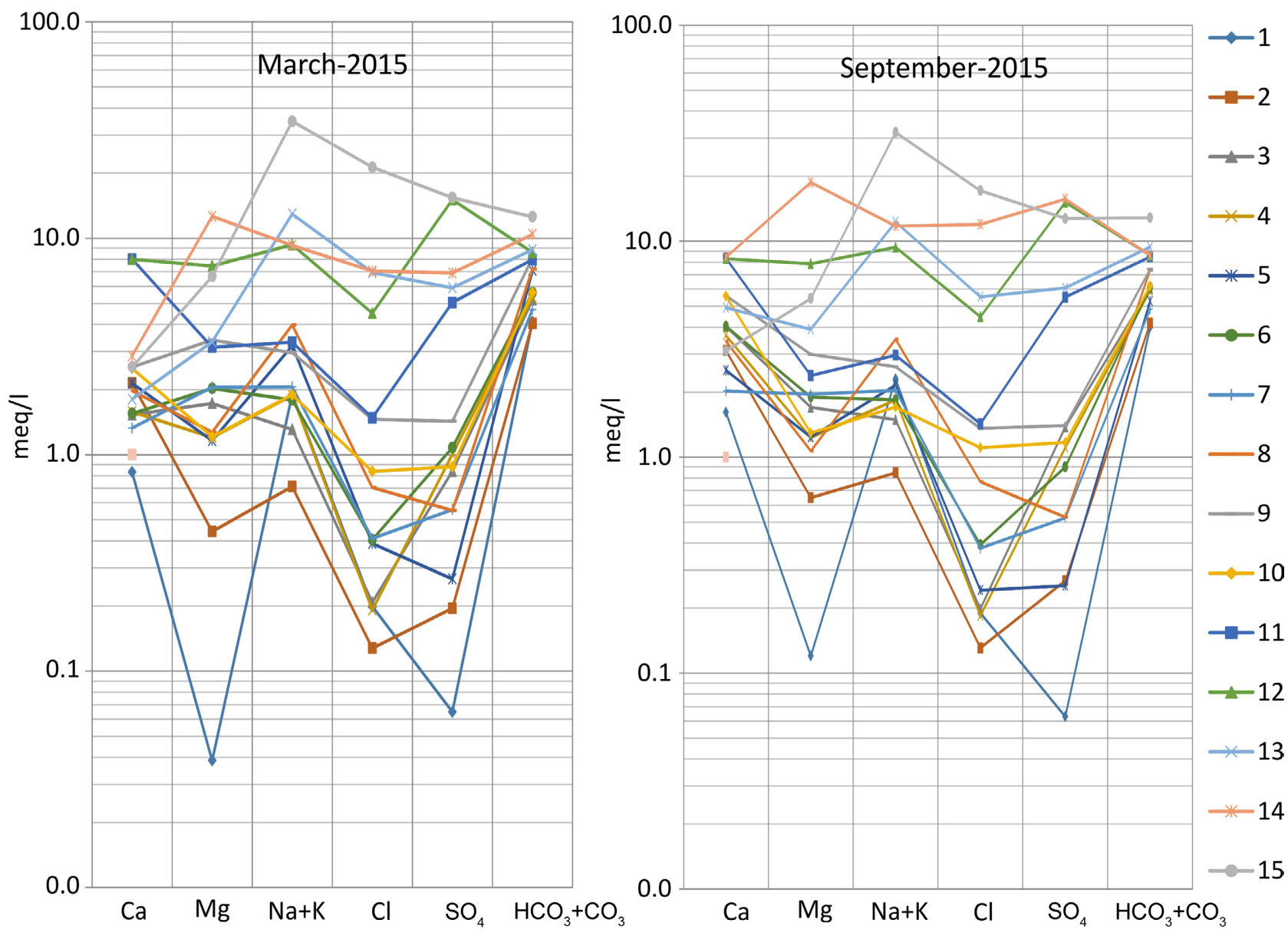

Figure 10. Schoeller diagrams.

in a narrow range.

\subsubsection{USA Salinity and Wilcox Diagram}

Samples that were collected upstream and in the vicinity of the Kazan district are mostly grouped in the $\mathrm{C}_{2} \mathrm{~S}_{1}$ class (medium salinity-low sodium hazard) in the USA salinity diagram (Figure 11(a)). Samples located near the downstream of Kazan are grouped in C3S1 (high salinity-low sodium hazard). Samples located in the central part of the plain are grouped in $\mathrm{C}_{4} \mathrm{~S}_{1}$ (high salinity and low sodium hazard), and, finally, the samples in the vicinity of Yenikent are grouped in $\mathrm{C}_{3} \mathrm{~S}_{2}-\mathrm{C}_{4} \mathrm{~S}_{2}$ (high salinity-medium sodium hazard or very high salinity-medium sodium hazard). Most of the samples fall in the "good to permissible" class in the Wilcox diagram (Figure 11(b)). Waters that are under the dominant effects of the evaporite bearing lacustrine formations are grouped in the "unusable" class.

\subsection{Comparison of the Chemical Data before and after the Stresses}

The chemical changes before and after the stress of the intensive groundwater extraction and sand-gravel mining in the Kazan plain were investigated. The DSI (1976) report is the unique source accessible, having original data recorded in 


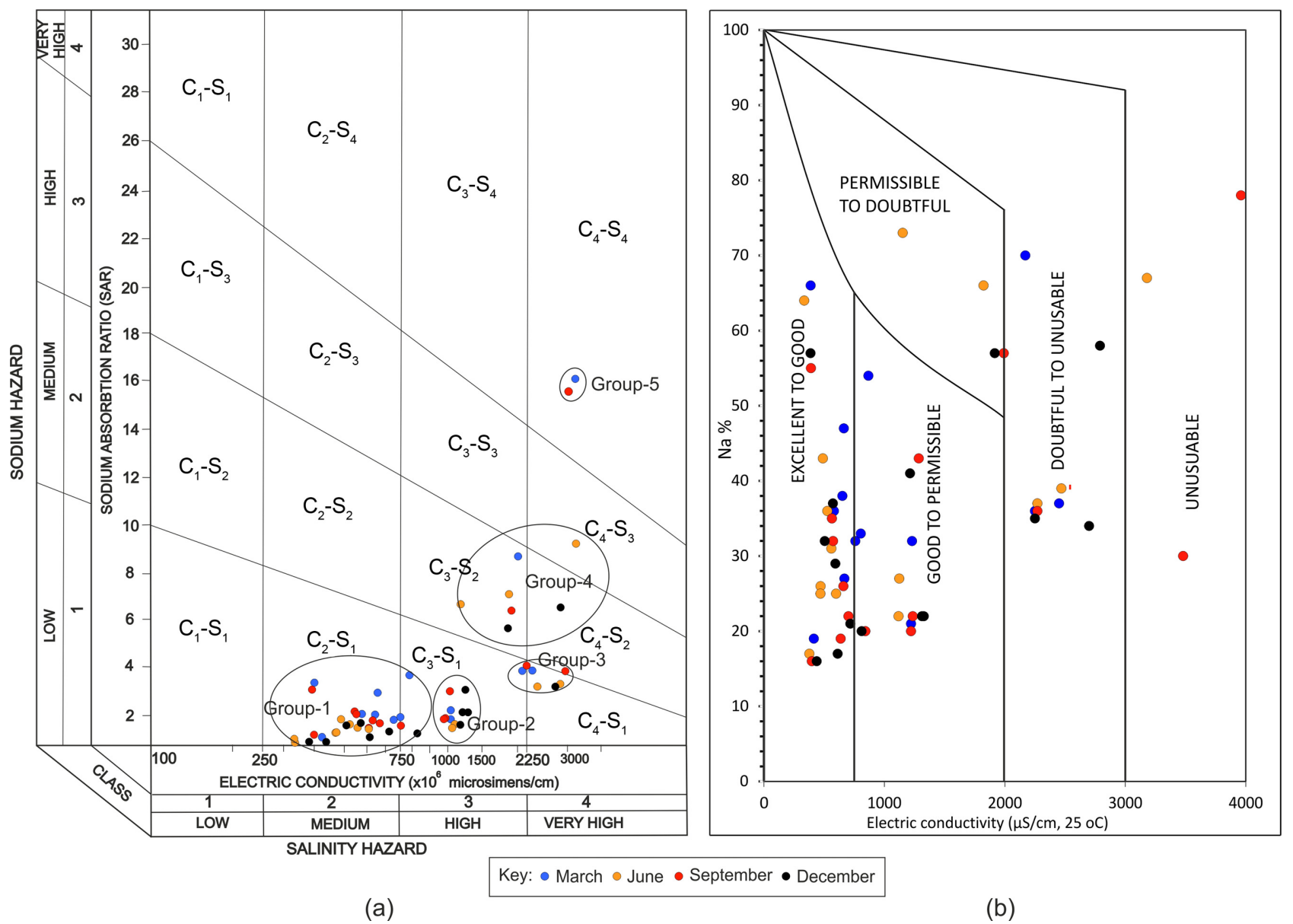

Figure 11. USA salinity (a) and Wilcox (b) diagrams.

the1960s and 1970s (Table 3). We must admit that the analysis method of the old samples is outdated and may contain some errors. However, these data that represent the groundwater system (Figure 12) are still comparable to the new data. For the former data, the EC changes between $480-600 \mu$ siemens $/ \mathrm{cm}$ in the upper part of the plain (upstream of Kazan). The average values of the EC of the current data (2015) are between $376-598 \mu$ siemens/cm. In both data sets, the water type is $\mathrm{Ca}-\mathrm{HCO}_{3}$. In the former and current data, the SAR range is 0.7 0.9 and $0.3-1.8$, respectively. According to the former data, the irrigation water class is $\mathrm{C}_{2} \mathrm{~S}_{1}$. Accordingly, there is no significant difference between the former and the current data upstream of the Kazan district. According to the former chemical data in the middle region (between Kazan and Batik), the EC range was between $480-1284 \mu$ siemens $/ \mathrm{cm}$, and, in the current data, the range was between $547-1226 \mu$ siemens $/ \mathrm{cm}$. For the former data, the SAR is between 0.7 3.4, and the irrigation water class is $\mathrm{C}_{2} \mathrm{~S}_{1}-\mathrm{C}_{3} \mathrm{~S}_{1}$. The former EC data downstream of the village of Coglu is $800-1000 \mu$ siemens $/ \mathrm{cm}$, the SAR is $0.8-2.6$, and the irrigation water class is $\mathrm{C}_{3} \mathrm{~S}_{1}$. All the waters in this region are the $\mathrm{Ca}-\mathrm{HCO}_{3}$ type, the same as the samples from 2015 . However, the $\mathrm{SO}_{4}$ and $\mathrm{Na}$ ions are notably high. When the former data in the midstream and downstream regions were 
Table 3. Chemical data (DSI 1975) of the groundwater in the Kazan Plain before over-exploitation and sand-gravel mining (between 1964 and 1970).

\begin{tabular}{cccccccccccc}
\hline Sample ID & $5282 \mathrm{~A}$ & $5334 \mathrm{~A}$ & 15030 & $5333 \mathrm{~A}$ & $5263 \mathrm{~A}$ & $5331 \mathrm{~A}$ & $5330 \mathrm{~A}$ & $5332 \mathrm{~A}$ & Spring-1 & Spring-2 & Spring-3 \\
\hline $\mathrm{pH}$ & 8.2 & 7.5 & 7.0 & 8.2 & 8.2 & 8.7 & 7.6 & 7.3 & 8.4 & 7.5 & 7.9 \\
$\mathrm{EC}(\mu \mathrm{S} / \mathrm{cm})$ & 600 & 880 & 1284 & 1000 & 480 & 1700 & 650 & 600 & 800 & 900 & 1000 \\
$\mathrm{Ca}+\mathrm{Mg}$ & 5.0 & 8.0 & 7.2 & 4.65 & 4.0 & 2.0 & 3.5 & 5.0 & 4.40 & 7.5 & 7.30 \\
$(\mathrm{meq} / \mathrm{l})$ & & & & & & & & & & & \\
$\mathrm{Na}(\mathrm{meq} / \mathrm{l})$ & 1.37 & - & 5.64 & 5.15 & 0.7 & 14.1 & 1.41 & 1.17 & 3.85 & 2.35 & 2.35 \\
$\mathrm{~K}(\mathrm{meq} / \mathrm{l})$ & 0.11 & - & - & 0.11 & 0.05 & 0.24 & 0.12 & 0.2 & 0.060 & 0.08 & 0.08 \\
$\mathrm{CO}_{3}+\mathrm{HCO} \mathrm{C}_{3}$ & 4.08 & 5.59 & 9.0 & 6.86 & 3.9 & 11.1 & 5.48 & 5.17 & 5.42 & 7.60 & 6.90 \\
$(\mathrm{meq} / \mathrm{l})$ & & & & & & & & & & & \\
$\mathrm{Cl}_{(\mathrm{meq} / \mathrm{l})}$ & 0.98 & 0.64 & 2.57 & 1.5 & 0.14 & 5.25 & 0.64 & 1.12 & 0.96 & 0.40 & 0.24 \\
$\mathrm{SO}_{4}(\mathrm{meq} / \mathrm{l})$ & 1.42 & 3.27 & 1.27 & 1.55 & 0.71 & 0.02 & 6.58 & 0.11 & 1.93 & 3.23 & 2.59 \\
$\mathrm{Na} \%$ & 21.1 & 15 & 43.9 & 52 & 14.7 & 86 & 21.4 & 18 & 46 & 15 & 24 \\
$\mathrm{SAR}$ & 0.9 & 0.7 & - & 3.4 & 0.5 & 14 & 0.9 & 0.7 & 2.6 & 0.8 & 1.20 \\
$\mathrm{RSC}$ & - & - & 0 & 2.21 & - & 9.1 & 0.14 & 0.14 & 1.02 & 0 & 4.22 \\
\hline
\end{tabular}

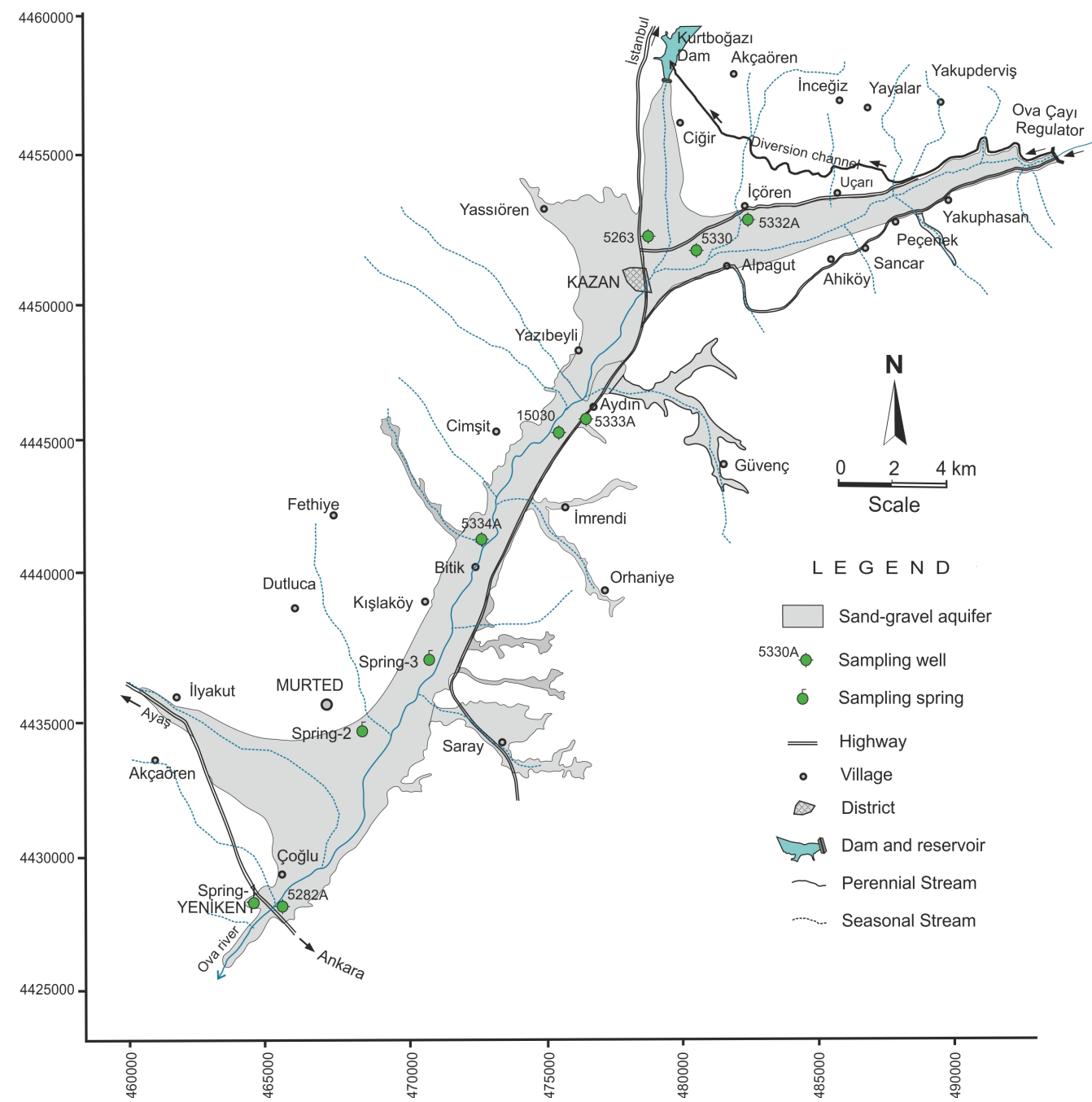

Figure 12. Location map of the former (before sand-gravel mining and over-exploitation) sampling wells in the plain. 
compared with the average data from 2015, the most significant point was that there is no notable difference between the old and the new in the middle section, but the former waters in the downstream region (downstream of the village of Batik) were fresher than today. When the former and current results were compared, it is was seen that, for the current water samples, the EC values were 2.5 4 times, $\mathrm{Na}$ and $\mathrm{Na} \%$ were 2 times, sulfate was 1.5 - 4 times, and SAR was 3 times higher. According to the former analysis, the irrigation water class was $\mathrm{C}_{3} \mathrm{~S}_{1}$. The irrigation water class has turned into $\mathrm{C}_{4} \mathrm{~S}_{1}-\mathrm{C}_{3} \mathrm{~S}_{2}$ and $\mathrm{C}_{4} \mathrm{~S}_{2}$ with the over-exploitation and sand-gravel mining.

\section{Conclusions}

The Kazan Plain in central Turkey is a dramatic example of a region where intensive sand-gravel mining and overexploitation took place, adding to the geogenic pollution. The productive sand-gravel aquifer in the plain has been substantially damaged due to the intensive sand-gravel mining that began in the 1980s. Additionally, over-exploitation with production wells has caused notable declines in groundwater levels, particularly in the 2000s. The decline reached 20 $\mathrm{m}$ (about half of the saturated thickness of the sand-gravel aquifer) in the İcoren region where the intensive groundwater abstraction lasted until 2010. Some quarries continued to operate until 2010 but after then, mining activity continued only at a minimum.

In the middle and downstream region of the plain, surfaced salt waters come from the evaporite-bearing lacustrine formation around the alluvial aquifer. However, the water quality used to be better than today, before the alluvial aquifer was subjected to over-exploitation and sand-gravel mining. The fresher groundwaters are present in the upstream parts of the plain that is not affected by the evaporitic lacustrine formation. There is no significant difference between the former (in the 1960s and 1970s) and the current chemical data in the plain except for the downstream region. There were significant differences in the downstream region (Coglu-Yeniken region) before and after the sand-gravel mining and over-exploitation. The groundwater in the downstream area is enriched with ionic content; in other words, it is salinized. Furthermore, storing the water of Kurtderesi Creek and Ovacayı Creek in the Kurtboğazı Dam since 1973 should have the effect of the stream discharge that recharged the groundwater system before. Thus, the fresh waters that in the past came from the upstream regions of the basin have come to an end.

The Ovacayi and Kurtderesi Rivers used to be recharged from the high elevated regions of the basin and brought fresh water to the plain. Storage of the fresh water in the Kurtbogazi Reservoir affected the groundwater quality negatively, particularly in the downstream area of the plain. This storage also may have caused some decrease in the water level with the excessive sand-gravel mining and overexploitation. Urbanization and industrialization may also have had an impact on groundwater quality. The degree and rate of each effect is a 
new research issue.

\section{Highlights}

- The Kazan Plain is under the pressure of over-exploitation and dense sandgravel mining activity.

- Analyzes were conducted to determine changes in the quantity and quality of groundwater.

- Water quality and level changes between 1980 and 2015.

- Groundwater quality has been significantly degraded due to the over-exploitation of sand-gravel mining.

\section{Acknowledgements}

The authors wish to express their sincere appreciation to the Turkish State Hydraulic Works (DSI) for their help in sampling and chemical analysis.

\section{Conflicts of Interest}

The authors declare no conflicts of interest regarding the publication of this paper.

\section{References}

[1] Khanlari, G., Heidari, M., Momeni, A.A., Ahmadi, M. and Beydokhti, A.T. (2012) The Effect of Groundwater Overexploitation on Land Subsidence and Sinkhole Occurrences, Western Iran. Quarterly Journal of Engineering Geology and Hydrogeology, 45, 447-456. https://doi.org/10.1144/qjegh2010-069

[2] Apaydin, A. (2012) Dual Impact on the Groundwater Aquifer in the Kazan Plain (Ankara, Turkey): Sand-Gravel Mining and Over-Abstraction. Environmental Earth Sciences, 65, 241-255. https://doi.org/10.1007/s12665-011-1087-8

[3] Huang, F., Wang, G.H., Yang, Y.Y. and Wang, C.B. (2014) Overexploitation Status of Groundwater and Induced Geological Hazards in China. Natural Hazards, 73, 727-741. https://doi.org/10.1007/s11069-014-1102-y

[4] Pophare, A.M., Lamsoge, B.R., Katpatal, Y.B. and Pawale, V.P. (2014) Impact of Over-Exploitation on Groundwater Quality: A Case Study from WR-2 Watersheds, India. Journal of Earth System Science, 123, 1541-1516. https://doi.org/10.1007/s12040-014-0478-0

[5] Kondolf, G.M. (1994) Geomorphic and Environmental Effects of In-Stream Gravel Mining. Landscape and Urban Planning, 28, 225-243. https://doi.org/10.1016/0169-2046(94)90010-8

[6] Kondolf, G.M. (1997) Hungry Water: Effects of Dams and Gravel Mining on River Channels. Environmental Management, 21, 533-551. https://doi.org/10.1007/s002679900048

[7] Sonak, S., Pangam, P., Sonak, M. and Mayekar, D. (2006) Impact of Sand Mining on Local Ecology. In: Sonak, S., Ed., Multiple Dimensions of Global Environmental Change, Teri Press, New Delhi, 101-121.

[8] Marquez, E.D., Sella, S.M., de Mello, W.Z., Lacerda, L.D. and Silva-Filho, E.V. (2007) Hydrogeochemistry of Sandpit Lakes at Sepetiba Basin, Rio de Janeiro, Southeastern Brazil. Water, Air, and Soil Pollution, 189, 21-36. 
https://doi.org/10.1007/s11270-007-9550-6

[9] Navarro, A. and Carbonel, M. (2007) Assessment of Groundwater Contamination Caused by Uncontrolled Dumping in Old Gravel Quarries in the Besòs Aquifers (Barcelona, Spain). Environmental Geochemistry and Health, 30, 273-289. https://doi.org/10.1007/s10653-007-9123-z

[10] Peckenham, J.M., Thornton, T. and Whalen, B. (2009) Sand and Gravel Mining: Effects on Groundwater Resources in Hancock County, Maine, USA. Environmental Geology, 56, Article No. 1103. https://doi.org/10.1007/s00254-008-1210-7

[11] Welhan, J. (2001) Ground-Water Interactions near the Highway Pond Gravel Pit, Pocatello, Idaho. Staff Report 01-3, Idaho Geological Survey, Moscow.

[12] Mahamat, H.B., Le Coz, M., Abderamane, H., Sardini, P. and Razack, M. (2017) Hydrochemical and Isotopic Characteristics of the Basement Aquifer in the Wadi Fira Area, Eastern Chad. Journal of Water Resource and Protection, 9, 1688-1708. https://doi.org/10.4236/jwarp.2017.913105

[13] Apaydin, A., Taner, O., Kavaki, T. and Güner, B. (1996) Kum-çakıl ocaklarının doğal çevreye, özellikle yeraltısularına olumsuz etkilerine çarpıcı bir örnek: Mürted Ovası (Ankara). Jeoloji Mühendisliği, 50, 33-38.

[14] Santo, E.L. and Sanchez, L.E. (2002) GIS Was Applied to Determine Environmental Impact Indicators Made by Sand Mining in a Floodplain in Southeastern Brazil. Environmental Geology, 41, 628-637. https://doi.org/10.1007/s002540100441

[15] Worrall, F. and Kolpin, D.W. (2003) Direct Assessment of Groundwater Vulnerability from Single Observations of Multiple Contaminants. Water Resources Research, 39, HWC 2-1-HWC 2-8. https://doi.org/10.1029/2002WR001212

[16] EPA (2008) Sampling and Analysis of Waters, Wastewaters, Soils and Wastes. Publication IWRG701-June 2009.

[17] DSI (1971) Ankara-Murted Plain Geophysical Resistivity Investigation Report. General Directorate of State Hydraulic Works (DSI) Fifth Regional Directorate, 11. (Unpublished)

[18] DSI (1975) Ankara-Murted Plain Hydrogeological Investigation Report. General Directorate of State Hydraulic Works (DSI), 49. (Unpublished) 